\title{
Economic mainstream and power: a profile analysis of Central Bank directors during PSDB and PT governments in Brazil
}

Mainstream econômico e poder: uma análise do perfil dos diretores do Banco Central do Brasil nos governos do PSDB e do PT

\author{
Adriano Codato \\ Universidade Federal do Paraná \\ Marco Cavalieri \\ Universidade Federal do Paraná \\ Renato Perissinotto \\ Universidade Federal do Paraná
}

Eric Gil Dantas

Universidade Federal do Paraná

\section{Abstract}

This paper analyses the professional and educational backgrounds of members of the Board of Directors of Central Bank of Brazil in the period between the beginning of Fernando Henrique's first term and the end of Dilma Rousseff's first term. The paper puts forward two novelties. First, a database synthesizing the information from the curricula of the abovementioned individuals. Second, modern literature in the field of methodology of economics is used to categorize the educational backgrounds of those individuals with education in economics. Our general findings point to a differentiation between two types of members in the Board of Directors. The first type is the one generally recruited for the positions concerned with organizational issues within the Bank, and the second is usually the one that occupies posts directly related to the decision making of economic policies. However, we did not identify significant differences between the types of individuals chosen by PSDB and PT governments.

\section{Keywords}

Brazilian Central Bank; bureaucratic elites; mainstream economics; Board of Directors of Central Bank of Brazil.

JEL Codes B50; E58.

\section{Resumo}

Este artigo faz uma análise das trajetórias profissionais e dos backgrounds educacionais dos diretores do Banco Central do Brasil que serviram desde o primeiro governo de Fernando Henrique Cardoso (1995) até o término do primeiro mandato de Dilma Rousseff (2014). O trabalho apresenta duas novidades. Primeiro, a elaboração de um banco de dados inédito sobre os currículos dos 39 diretores que atuaram nos governos no periodo mencionado. Segundo, a utilização da literatura em metodologia da Economia para a caracterização dos backgrounds educacionais dos diretores com formação em Economia. Os resultados mais gerais apontam para uma diferenciação entre o tipo de diretor recrutado para as diretorias envolvidas com decisões de política econômica e para aquelas que lidam com questões organizacionais do banco. Entretanto, não há diferença significativa entre o tipo de diretor escolhido pelos governos do PSDB e do PT.

\section{Palavras-chave}

Banco Central do Brasil; elites burocráticas; mainstream econômico; diretores do Banco Central do Brasil.

Códigos JEL B50; E58. 
The economic literature on Central Banks is vast and varied: it comprises theoretical and empirical works, research on monetary policy and regulation, and institutional histories. For each of these subjects, Economics discusses Central Banks from the point of view of different theoretical and methodological perspectives. However, economists are usually not familiar with studies on Central Banks from the perspective of Political Science or Political Sociology, in which they are analyzed first and foremost as government institutions where stable bureaucracies and political elites have the power to make decisions that affect society as a whole.

In general terms, this Political Science and Political Sociology literature can be divided into two areas of interest. On one hand, there are works discussing whether these institutions can or ought to ensure mechanisms of horizontal accountability in relation to other government agencies (ministries, the Congress, the President, etc), or mechanisms of vertical accountability towards society at large. In these cases, as observed by Sola, Garman and Marques (2002, p.121), the question is to whom central bankers should be accountable. The entire debate over the autonomy or heteronomy of Central Banks in institutionalized polyarchies derives from this literature. ${ }^{1}$ On the other hand, there are studies that consider the sociography of the directors of these institutions, keeping track of their respective academic training, careers in government, market and/or international agencies before being recruited to work for the monetary authority (Farvaque et al., 2009; Lebaron, 2010; Adolph, 2013; Loureiro, 1992; Novelli, 1999; Olivieri, 2007). Debates concerning the networks of vested economic and/or social interests these actors may be implicated in stem from such researches. This article is a contribution to this second category of studies (the background and career analysis of central bankers). Its findings, however, can serve to fuel the debate that drives research in the first field (namely, the accountability of Central Banks). The findings can also interest economists, since it is somewhat pointless to discuss the independence of a government institution without considering to whom autonomy must be granted.

Our objectives are twofold. The first one is to describe and analyze the educational background and career profile of Brazilian Central Bank (BCB) directors who served during the first Fernando Henrique Cardoso government (1995-1998), second Cardoso government (1999-2002), first

1 See Sola, Garman and Marques (Sola et al., 2002), Raposo (2011) and Albuquerque (2008). 
Luiz Inácio Lula da Silva government (2003-2006), second Lula government (2007-2010), and first Dilma Rousseff government (2011-2014). The second goal is to verify the existence of any patterns when comparing different $\mathrm{BCB}$ directorate areas - those dedicated to formulating political economy and those responsible for administrative matters - and the profile of their members. This study not only intends to innovate by updating information and broadening the profile analysis of BCB directors (Loureiro, 1997; Novelli, 1999; Olivieri, 2007) but it also seeks to look more carefully at the affiliation of actors in the BCB directing body in terms of the different "schools" of economic thought based on their academic backgrounds in the field. According to Göhlmann and Vaubel (2007) and Farvaque et al. (2009), academic training in Economics, as well as professional profiles linked to certain academic centers, implies a more conservative stance towards tolerance to inflation. For Lebaron (2010), this kind of background and profile is explicitly linked to what he called the economic mainstream. Building upon the fact that Brazilian academia is uniquely plural in terms of different types of training and theoretical affiliations in economic thought, and admitting that a deeper discussion is needed as to the definition of the strands of economic thought among us, we have included the literature on economic methodology in order to define the concept of mainstream. This category is defined in relation to "orthodoxy", "heterodoxy", and "neoclassicism". Incorporating this subject in Political Science, as well as bringing into Economics an emphasis on the profile of directors of these institutions, is a form of building a multidisciplinary field and may represent progress in the literature in both fields.

Taking this into consideration, we intend to test the hypothesis that the profile of the members of directing bodies of the BCB varies significantly according to their functional responsibilities, that is, to whether they are responsible for the decision making of economic policies or for internal administrative matters,. To be more specific, our hypothesis suggests that in the case of the directing bodies responsible for economic policy, directors tend to be recruited outside the bureaucratic cadres of the $\mathrm{BCB}$, especially from the financial system, and usually have academic backgrounds in mainstream economic schools. On the other hand, for bodies responsible for internal and/or administrative matters, members tend to be recruited among public servants that have been admitted into BCB through public examinations, as already pointed out by Olivieri (2007). 
This article is divided into four parts. The first part summarizes and discusses the Political Science literature on directing bodies of Central Banks, including research data from previous studies conducted in Brazil. Next, we present our data concerning the professional trajectories of $\mathrm{BCB}$ directors. In the third part we focus on education backgrounds. This third section, however, begins with a review of the literature in the field of Economic methodology in order to support our classification of Brazilian and foreign institutions in which $\mathrm{BCB}$ directors obtained their degrees in Economics. We also used data from rankings and other empirical studies on the profiles of Economics departments and the scientific output of economists in order to support our conclusions. Next, in our concluding section, we present the findings of this study and debate its meaning. Here we analyze the attributes of $39 \mathrm{BCB}$ directors in the five governments mentioned above, of which 21 served in twelve years of PT governments and 18 in eight years of PSDB governments. ${ }^{2}$

The study of the biographical profiles of $\mathrm{BCB}$ directors in Brazil is based on the curriculums available in the Senate Gazette and its bank of Official Messages. Pursuant to the 1988 Constitution, the Brazilian Senate must approve the appointment of BCB's president and directors. Only a few cases required us to resort to other sources, such as pieces in the press, CNPq Lattes platform [a database created by the Brazilian research agency containing the academic training and output of all researchers it funds], documents of the Parliamentary Commission of Inquiry of the Chamber of Deputies and documents elaborated by the American Economic Association with annual reports of doctorate degrees granted.

\section{The literature on central banks governing bodies}

\subsection{Professional origins and economic decision: the international literature}

In Bankers, Bureaucrats, and Central Bank Politics, Adolph (2013), analyzing the recruitment of Central Bank policymakers from all over the world, deals

2 In this time span (1995-2014), many of these administrators were appointed to more than one directing position. We considered only the first appointment. In this sense, the five directors appointed to $\mathrm{BCB}$ during Itamar Franco government maintained in the first Cardoso 
with the influence of career trajectories in the formation of individual preferences and, consequently, in the formulation of monetary policy. According to the author, there are two basic professional backgrounds of central bank directors, they are either from the "financial sector" or "government", and Central Banks are usually the transition between time spent in either of these sectors. The flow chart below (Figure 1) is presented by Adolph as a refutation of the "myth of the impartiality of the bureaucracy". For the author, "career paths tell us where agents have been and where they are likely to go" (Adolph, 2013). Hence, the constant fluctuation observed consists of periods in the government or the financial sector with transitional stages with longer or shorter time length in Central Banks. ${ }^{3}$

\section{Figure 1 Career paths of Central Bank directors and institutional contexts}

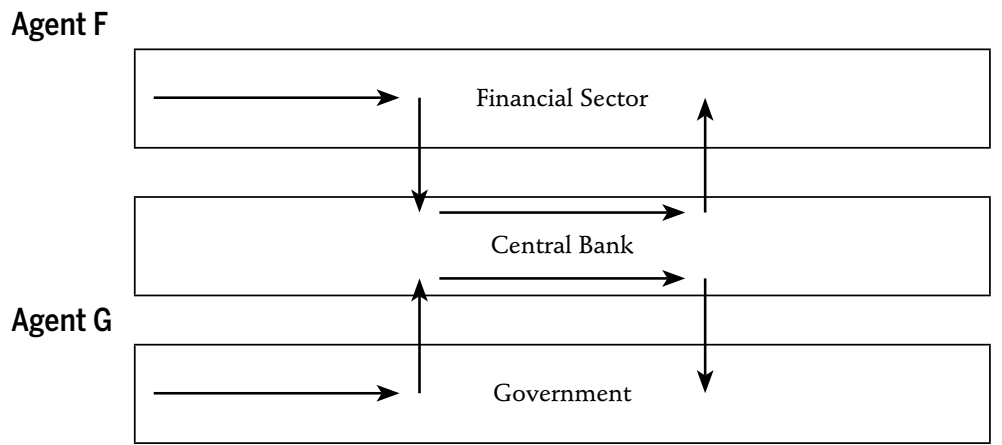

Source: Adolph, 2013.

The careers of directors of State agencies are one of the elements that must be analyzed in order to understand the functioning of government institutions and to predict its decisions. Careers originating exclusively in the "State" (the public bureaucracy) or in the "market" (financial sector) are

government were taken into account. There is also the case of four directors appointed during the second Cardoso government and stayed during the first few months of Lula government. Only one director, appointed in 1997, stayed until 2006 (during the PSDB and PT governments). 3 Although some of the international literature also charts the paths of agents after they leave these bodies, the lack of data concerning what happens after directors exit prevented any similar analysis. Information in the press of this nature is rare, even in the case of presidents, who are much more public figures. The curriculums we had access to contained only activities prior to appointment (with the selection and bias imprinted by the agent himself). Thus our analysis will limit itself to backgrounds, whether educational or professional. 
decisive in order to understand the degrees of autonomy of State agencies. Specifically, the constant circulation of directors between the State and the market could partially explain the behavior of Central Banks regarding monetary policy. Thus, according to Adolph,

Understanding central bankers' monetary policy preferences begins with central bankers' career paths and career concerns. A central banker's career background may influence his personal beliefs about the ideal tradeoff between inflation and output stability, while at the same time providing the basis for an exchange: future careers for the central banker policy influence for the shadow principal providing the central banker's next job (Adolph, 2013).

For Adolph (2013), director's ambition to advance in their personal careers may influence their policy preferences and decisions, at least indirectly. The perspective of going upward, whether inside or outside the organization, whether public or private, creates an incentive to please not only direct superiors, but also anyone that might be helpful.

In this vein, educational training and occupational background, alongside career ambition, function as factors of influence on policies adopted by central bankers, as Göhlmann and Vaubel (2007) reveal. In studying the professional origin and training of members of Central Bank boards (the equivalent to the diretorias, or directories, of Brazilian Central Banks) of ten European countries, the United States and the European Central Bank, Göhlmann and Vaubel (2007) emphasized that these two variables can considerably explain the performance of Central Banks regarding inflation:

Education and occupational career affect the inflation performance of central bankers because they convey knowledge about the causes and effects of inflation. In addition, professional experience may generate personal loyalties to special interest groups: a profession or industry, a party, a bureaucracy, an income group etc. (Göhlmann; Vaubel, 2007).

The study conducted by Farvaque, Hammadou and Stanek (2009), with 175 presidents of nine central banks from 1999 to 2008, convincingly showed that the type of professional experience of members of committees of monetary policy of the main OCDE countries (the private sector, academia, central bank bureaucracy), and even the gender of the director, also have an impact on the type of decision relative to inflation. The authors discovered that there are different prevailing configurations in the composition of these committees. The board of the European Central Bank is dominated by "public economists" while in Australia by "private sector economists" and in Canada by "central bankers" (those whose career paths originated in the bank). 
In addition, the possible impact of distinct biographic experiences on political choices, cognitive disposition and cultural differences was shown by Lebaron (2010). According to the author, "the behaviors of central banks are at least partially explained by the features of their committee members, the kind of social assets they have accumulated and the dispositions that come with these assets" (Lebaron, 2010, p. 298). Lebaron also points out the increased internal recruitment of central banks, suggesting that this might have been happening since the 1980s due to the "push for the "independence" of central banks.

However, none of these studies consider the background of actors involved in terms of affiliation to strands of economic thought. They simply analyze whether backgrounds include specific training in Economics or other fields. Two considerations lead us to believe that this sort of analysis requires improvement. First, Economics and especially macroeconomics and/or monetary economy are divided into several strands, among which there are many different opinions in terms of inflation and how Central Banks must act. Within this division there is an additional divide between the mainstream and what we can call the heterodoxies in Economics. However, also within the mainstream there are also divergences. In this regard, this study will leave aside these internal divisions within the mainstream due to a second consideration. The conclusions of this study must be employed with caution. It is necessary to consider that Brazil is rather unique in terms of its intellectual and institutional plurality. In several undergraduate and graduate schools, different perspectives are taught, begetting a quite different academic environment from that found in the US and, increasingly, in Europe. Thus separating economists with strictly mainstream schools training from those that were exposed - especially at the graduate level - to strands opposed to it is particularly interesting in the Brazilian case. Here, in addition to the fact that central bankers can be chosen from among economists and non-economists, the former can be selected from a broader pool of Economic theories and methodologies.

\subsection{The logic of selection of Central Bank directors in Brazil}

Loureiro (1997), Novelli (1999) and Olivieri (2007) analyzed the profile and origin of Brazilian Central Bank directors in distinct periods, in addition 
to other correlated issues such as the predominant form of recruitment, academic training and social network building in the processes of selection and appointment to posts.

Loureiro (1997) reconstructs the origin both of directors as well as BCB presidents from its creation until 1995. Taking into consideration only the case of directors, Loureiro demonstrates that between 1965, the year of its creation, and 1995, of the 50 directors who served the Bank, $28 \%$ were from academia, $26 \%$ were recruited from the private sector, while $46 \%$ were already part of the institution, i.e. part of the bank's bureaucracy. Among them, $64 \%$ had graduate degrees, almost half of them $(43.7 \%)$ from US universities.

However, the presentation of data in an aggregated fashion hides a change in the profile of directors recruited in different governments after the military regime (19640-1985). Novelli (1999, p. 118) observes that:

Of the 73 directors that served BCB since Figueiredo government, 30 (41\%) - regardless of where their careers began - present some sort of tie to the private financial system. Directors who had such ties were 3 (25\% of the total) in Figueiredo government; in the "team" chosen by elected president Tancredo Neves, $5(62 \%)$; 9 (43\%) in Sarney government; $5(50 \%)$ in Collor government; $5(38 \%)$ in Itamar Franco government; and $3(33 \%)$ in Fernando Henrique Cardoso government.

Figueiredo government (1979-1985) marked a decisive turn in the formation of BCB cadres. Decision-making positions used to be occupied by Banco do Brasil staff members allocated at the Superintendence of Currency and Credit (Superintendência da Moeda e do Crédito - SUMOC). Afterwards, there was a shift towards what Loureiro calls "private initiative" and Novelli (1999) describes as originating from the private financial system.

Olivieri (2007) took a step forward advancing an explanation of the logic behind the process of bureaucratic appointment of the Brazilian Central Bank and for the selection of its directors. His study outlines the profiles of 13 presidents and 55 central bank directors from 1985 to 2000, dividing the directing bodies into two categories: (i) monetary and exchange rate policies making; ${ }^{4}$ and (ii) supervision, regulation and administration. ${ }^{5}$ The former are in charge of the elaboration of economic policy

4 Includes the following boards: Banking (Diban), Market Capitals (Dimec), External Affairs (Direx), Monetary Policy (Dipom) and Economic Policy (Dipec).

5 Includes the following boards: Oversight (Difis), Administration (Dirad) and Regulation (Dinor). 
and thus are informally linked to the Presidency, which has a special interest in the appointment of its members. The latter are involved either in supervision and regulation matters or in internal organizational issues of the Central Bank.

According to Olivieri (2007, p. 154), policymakers in the monetary policy directorates did not formerly belong to the Central Bank and are recruited in their majority from both the financial system and educational institutions (78\%, or 25 of 32 agents). In the case of those in the supervision, regulation and administration directorates, the majority was recruited from among the regular BCB (75\% of the cases -18 out of 24$)$. In total, between 1985 and $2000,56 \%$ of the directors were recruited outside BCB, while the other $44 \%$ were bureaucrats admitted through public examinations, with singularities concerning their origins and type of post occupied. Olivieri (2007) also analyzed the social networks responsible for selecting $\mathrm{BCB}$ directors, outlining some former presidents of the Republic, former presidents of $\mathrm{BCB}$ and former Ministers of Finance, as the greatest detainers of appointment power. We can therefore conclude that $\mathrm{BCB}$ usually adopts different criteria to fill in posts in its different types of directorate posts, an information that is lost when data is approached in an aggregated form. (Loureiro, 1997; Novelli, 1999).

However, the analysis of professional trajectories (the sources of recruitment) does not exhaust the study of the variables involved in the process of appointment of central bankers. A more complex view of this process requires us to take into consideration the role of university education and economic ideas in shaping the perspective of decision makers concerning economic policy. In this regard, Loureiro (1997) classifies two educational institutions that figure prominently in the training of central bankers Fundação Getúlio Vargas (more specifically, the Graduate School in Economics, the EPGE, in Rio de Janeiro) and PUC-RJ (more specifically its Economics department) - as "privatistic" and in line with the interests of private banks.

In terms of differentiation of professional strategies, the end of the spectrum occupied by EPGE and PUC-Rio can be termed 'privatistic' not only due to the fact that both are private educational institutions but also because they emphasize the role of the market in the economic system. Furthermore, they maintain close ties to private enterprises, especially banks, to whom they serve as consultants.

This rather schematic approach is however important in order to verify whether these two institutions remain central in BCB's recruitment pro- 
cess. Nevertheless, Loureiro disregards any specific analysis from the field of economic methodology to distinguish educational backgrounds. Her conclusions concerning EPGE-FGV and PUC-RJ Economics Department seem to establish an automatic link between the intellectual training in these institutions and activities in the private sector. In this article, we refine the criteria of classification. We discuss the type of background in economics considering the literature on economic methodology.

In the following section, an analysis of $\mathrm{BCB}$ directors appointed by PSDB (1995-2002) and PT (2003-2014) governments is presented, regarding their professional backgrounds. The third section presents a deeper discussion on the economic schools of thought, educational institutions and intellectual backgrounds.

\section{The origins of central bankers}

Table 1 presents the number of BCB directors appointed since the 1990s, who served in FHC I and II, Lula I and II and Dilma I governments. The analysis considered all 39 individuals who served at least once in BCB directing boards. Of this total, 21 were appointed by PT in 12 years of government (2003-2014) and 18 by PSDB, including those appointed during Itamar Franco government who stayed in Cardoso government.

The first Lula government (2003-2006) chose the highest number of central bankers in the series (ten) - one more than the second Cardoso term. In the case of Lula I, this was due to the change of the incumbent party in the Presidency and consequently the change in command of the Central Bank. In addition, there was an important change in the ministry of finance. Guido Mantega substituted Antônio Palocci as minister of finance; they were two ministers with very distinct economic policy orientations (Barbosa; Souza, 2010; Morais; Saad-Filho, 2011). Dilma I government made the least number of appointments - only three directors. This was due perhaps to the continuity of the same Minister of Finance of Lula II government (Guido Mantega), despite the change at the top of the Central Bank.

Considering this group of 39 individuals as a whole, the predominant profile or "typical director" presents the following traits: almost all are men (37 out of 39), and they enter the posts with ages 40 to 50 (albeit entry in $\mathrm{BCB}$ might have occurred previously). The lowest age registered was 35 
and the highest 60 . Of the two women who occupied posts, one was appointed during PT governments and the other during PSDB governments.

Table 1 Number of directors appointed to the Brazilian Central Bank according to governing party (executive branch), President, and Minister of Finance

\begin{tabular}{|c|c|c|c|c|c|}
\hline $\begin{array}{l}\text { Main political } \\
\text { party }\end{array}$ & President & Minister of Finance & $\begin{array}{l}\text { Appointed } \\
\text { Director }\end{array}$ & $\%$ & Total \\
\hline \multirow[t]{5}{*}{ PMDB } & \multirow[t]{5}{*}{$\begin{array}{l}\text { Itamar } \\
(1992-1995)\end{array}$} & $\begin{array}{l}\text { Paulo Haddad } \\
(16 / 12 / 1992-1 / 3 / 1993)\end{array}$ & 0 & \multirow[t]{5}{*}{12.8} & \multirow[t]{5}{*}{5} \\
\hline & & $\begin{array}{l}\text { Eliseu Resende } \\
(1 / 3 / 1993-19 / 5 / 1993)\end{array}$ & 2 & & \\
\hline & & $\begin{array}{l}\text { Fernando H. Cardoso } \\
(19 / 5 / 1993-30 / 3 / 1994)\end{array}$ & 3 & & \\
\hline & & $\begin{array}{l}\text { Rubens Ricupero } \\
(30 / 3 / 1994-6 / 7 / 1994)\end{array}$ & 0 & & \\
\hline & & $\begin{array}{l}\text { Ciro Gomes } \\
(6 / 7 / 1994-1 / 1 / 1995)\end{array}$ & 0 & & \\
\hline \multirow[t]{2}{*}{ PSDB } & $\begin{array}{l}\mathrm{FHCl} \\
(1995-1998)\end{array}$ & \multirow[t]{2}{*}{$\begin{array}{l}\text { Pedro Malan } \\
(1 / 1 / 1995-1 / 1 / 2003)\end{array}$} & 4 & \multirow[t]{2}{*}{33.3} & \multirow[t]{2}{*}{13} \\
\hline & $\begin{array}{l}\text { FHC II } \\
(1999-2002)\end{array}$ & & 9 & & \\
\hline \multirow[t]{4}{*}{ PT } & \multirow[t]{2}{*}{$\begin{array}{l}\text { Lula I } \\
(2003-2006)\end{array}$} & $\begin{array}{l}\text { Antonio Palocci } \\
(1 / 1 / 2003-27 / 3 / 2006)\end{array}$ & 8 & \multirow[t]{4}{*}{53.8} & 10 \\
\hline & & \multirow{3}{*}{$\begin{array}{l}\text { Guido Mantega } \\
(27 / 3 / 2006-1 / 1 / 2015)\end{array}$} & 2 & & \\
\hline & $\begin{array}{l}\text { Lula II } \\
(2007-2010)\end{array}$ & & 8 & & 8 \\
\hline & $\begin{array}{l}\text { Dilma I } \\
(2011-2014)\end{array}$ & & 3 & & 3 \\
\hline \multicolumn{5}{|l|}{ Total } & 39 \\
\hline
\end{tabular}

Source: Observatory of social and political elites of Brazil (UFPR).

According to data, central bankers may originate from the institution's cadre, other agencies in the public administration, international agencies, educational institutions (mainly universities) or financial sector. During the period analyzed in this investigation, $77 \%$ of the directors served in positions in international agencies before landing in BCB (World Bank, IMF, UNPD/ $\mathrm{UN}$ and so forth). It is not uncommon for agents to occupy multiple posts or to exit the bank and then return to the Bank's cadres. Before becoming president of $\mathrm{BCB}$ during Dilma administration, for instance, Alexandre 
Trombini served successively in three direction boards (Dinor, Direc and Direx). Alkimar Moura, another researched subject, served between 1994 and 1997 in two different directorate posts (Dinor and Dipom).

Table 2 overlaps data concerning the party in government at the time of the appointment with the career path of the appointee. As the biographies of the directors are extensive and varied, encompassing many periods in several public and private institutions, we condensed their professional backgrounds into three categories: "government", "market", and "academia". These all-encompassing categories decrease the specificity of individual career paths, but, for a universe of only 39 individuals, the multiplication of classifications implies an exaggerated dispersion of data, which render infeasible the determination of overall trends and collective profiles. We know that the diversity of sectors in the professional backgrounds of decision makers is an important trait in their biographies (Marcussen, 2000 apud Lebaron, 2010) and this attribute is indeed at the root of the network of contacts and influencing capabilities they have to support their appointments.

However, in line with a significant number of studies on recruitment, we considered only the professional position immediately prior to recruitment to BCB. Methodologically, this option is justified since, given the diversity of career paths, it would be difficult to formulate an unequivocal measure concerning the sector of origin of the individual using all their previous positions. For this reason, this alternative is the one suggested by several studies on political elites employing the variable "professional sector of origin" (Rodrigues, 2002; Perissinotto et al., 2007; Daalder; Beerg, 1982)6. Thus, it is possible to note that, for the category "government", the vast majority comes from $\mathrm{BCB}$, but also, to a lesser extent, from international agencies, such as the United Nations Development Program (UNPD), World Bank and International Monetary Fund. In the category "market", in turn, almost all come from corporations linked with the financial system, from banks to consulting firms. Lastly, the category "academia" is composed by educational and research institutions.

PT governments recruited the majority of directors from BCB's own cadres $(57 \%)$, followed by those who came from the financial market (33\%) and very few from academia. PSDB governments also resorted to BCB's bureaucracy to fill in its directing boards (44\%), but yet they brought to these 6 For a methodological discussion on the subject, see (Codato et al., 2014; Sawicki, 1999; Offerlé, 1999). 
positions many more academics than PT (28\% compare to only 9.5\%). PSDB chose a lower percentage of agents with origins in the financial system than PT (28\% compared to $33.3 \%$ ). The adjusted standardized residuals within critical limits7 reveal that PT (center-left) and PSDB (center-right) governments are statistically indistinguishable regarding the professional backgrounds of agents recruited to fill in director positions in BCB.

Table 2 Professional backgrounds of directors appointed to Central Bank of Brazil by main party in the government coalition

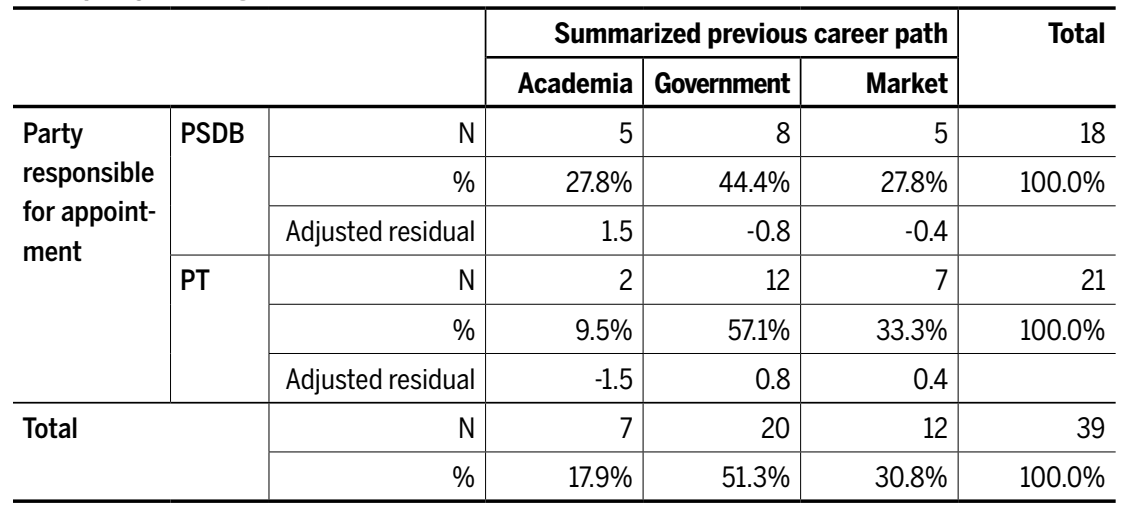

Source: Observatory of social and political elites of Brazil (UFPR).

Note: Value Cramér's V = 0.238; Approx. Sig. 0.333

This lack of association between the dominant party in the government coalition and the professional backgrounds of directors could suggest two things. First, that the maintenance of the political orientation of the ("orthodox") economic policy from the second Cardoso government to the first phase of the Lula government, despite personnel changes (as shown in Table 1), did not profoundly change the "director-type" profile of BCB.8

7 If the adjusted standardized residuals lie within the -1.96 and 1.96 interval therefore the count observed in this cell is similar to the expected count, or similar to the average. Therefore "all is quiet on the front". When these residuals are lower than -1.96 the cell "has a significantly lower behavior than expected[...] When the residuals are situated [...] above 1.96 it means that this cell is behaving above the expected, higher than the average" (Pestana; Gageiro, 2008, p.133). Thus, the higher the residuals, greater the association (negative or positive).

8 Novelli $(2010$, p.235) reports this process of director changes yet maintaining BCB policies as the result of the professional and intellectual background of the new incumbents: "Beny Parnes, an economist with a degree from PUC-RIO and director of BBM bank was appointed during Cardoso government in 2002 to the International Affairs Directory and remained there until 2003, when he was replaced by Alexandre Schwartsman, PhD in Economics from the University of California - Berkeley, a World Bank economist and economist-in-chief of banks 
Second, that BCB has reached a mature level of institutionalization and accordingly a relative autonomy before the political orientation of the Executive Branch. Furthermore, the technical nature of the work of a central banker tends to produce and impose the necessity of self-recruitment from its own cadres. The study conducted by Lebaron with 308 European central bankers between 1995 and 2009 showed that approximately $30 \%$ of them started their career paths in the central banks and $40 \%$ had previous central bank experience at some point in their careers (Lebaron, 2010).

Table 3 Professional backgrounds of directors appointed by the Brazilian Central Bank by specialty of directory

\begin{tabular}{|c|c|c|c|c|c|c|}
\hline & & & \multicolumn{3}{|c|}{ Prior career path (simplified) } & \multirow[t]{2}{*}{ Total } \\
\hline & & & Academia & Government & Market & \\
\hline \multirow{6}{*}{$\begin{array}{l}\text { Economic } \\
\text { policy } \\
\text { directory } \\
\text { boards }\end{array}$} & \multirow[t]{3}{*}{ No } & $\mathrm{N}$ & 1 & 16 & 2 & 19 \\
\hline & & $\%$ & $5.3 \%$ & $84.2 \%$ & $10.5 \%$ & $100.0 \%$ \\
\hline & & Adjusted residual & -2.0 & 4.0 & -2.7 & \\
\hline & \multirow[t]{3}{*}{ Yes } & $\mathrm{N}$ & 6 & 4 & 10 & 20 \\
\hline & & $\%$ & $30.0 \%$ & $20.0 \%$ & $50.0 \%$ & $100.0 \%$ \\
\hline & & Adjusted residual & 2.0 & -4.0 & 2.7 & \\
\hline \multirow{2}{*}{\multicolumn{2}{|c|}{ Total }} & $\mathrm{N}$ & 7 & 20 & 12 & 39 \\
\hline & & $\%$ & $17.9 \%$ & $51.3 \%$ & $30.8 \%$ & $100.0 \%$ \\
\hline
\end{tabular}

Source: Observatory of social and political elites of Brazil (UFPR).

Note: Value Cramér's V = 0.642; Approx. sig, $=0.000$.

When analyzing the career paths of directors by type of position occupied in the $\mathrm{BCB}$, there are, nonetheless, important differences. As shown in Table 3 , in the departments in charge of the formulation of the main and stock brokers. Schwartsman was replaced by Paulo Vieira da Cunha, PhD in Economics, with a degree from the University of California - Berkeley, a World Bank economist, an IMF economist with experience in private financial institutions (Lehman Brothers and HSBC). The Economic Policy was headed by Afonso Bevilaqua, a PUC-RJ professor, also with a $\mathrm{PhD}$ from Berkeley, and a consultant for multilateral financial institutions. Bevilaqua was substituted by Mario Mesquita, Phd in Economics, with a degree from Oxford University (UK), an $\mathrm{IMF}$ economist and also with experience in private financial institutions (ABN AMRO), and he also accumulated the post of Director of Special Studies since June 2006. The Directory of Monetary Policy was occupied by Luiz Augusto Candiota, a PUC-RJ economist and a former director of Citibank. He was replaced by Rodrigo Azevedo, $\mathrm{PhD}$ in Economics (University of Illinois) and former director of Credit Suisse First Boston. The Directory of Special Studies was late occupied by Eduardo Loyo, a PUC-Rio economist with a $\mathrm{PhD}$ in Economics degree from Princeton. He was replaced by Alexandre Tombini, a BCB cadre, who until then was senior advisor for Brazil in IMF." 
guidelines of economic policy - the economic policy, monetary policy and International Affairs and Corporate Risk Management departments - there is a prevalence of agents with experience in private finance institutions $(50 \%)$, in comparison to a lower percentage of bureaucrats $(20 \%)$ and academics (30\%).

The opposite is true for directories not in charge of economic policy, in which the presence of in-house cadres is vastly prevalent (84\%), with an adjusted residual of 4.0 (well over the critical limit of 1.96). Tests showed a moderately strong association between the variables (Cramér's $\mathrm{V}=0.642$ and approx. sig. $=0.000$ ).

\section{Economic thought and educational backgrounds}

In this section, our goal is to investigate the intellectual training of the agents and the types of departments they control. It is important to stress that this paper does not analyze the possible relationships between educational training and the preferences concerning economic policy decisions.

Before presenting the data, we must discuss the concepts of mainstream, orthodox, heterodox and neoclassical economics. As emphasized above, a novel feature of this study is the resort to the literature in the field of economic methodology in order to categorize the educational background of the economists that served at BCB. Although we only use the concept of mainstream to categorize the studied directors, we believe that it is important to discuss the other concepts for three reasons. First, because the mainstream is often used interchangeably with orthodoxy. This confusion, particularly when orthodox is used to describe an orientation towards monetary policy and fighting inflation, must be avoided..$^{9}$ In this regard, "orthodoxy" does not refer only to restrictive policies in terms of inflationary control, but it is also used from the methodological-theoretical point of view, as we shall define ahead. Second, we must also consider that in the Brazilian academia heterodox approaches are significantly present, much more than in the American academia, for instance. Therefore, the hetero-

9 The concepts of mainstream and orthodoxy strive to be definitions applicable for the Economic Sciences as a whole, conferring it a more methodological character. In the study of Brazilian economics, for example, it is quite common to make the link between the categories of orthodoxy and heterodoxy to inflation combatting policies. These usages for example are found in Giambiagi et al. (2011), Fonseca (2010), Andrade, Mollo e Silva (1998). 
doxy is sometimes an important contestant in the debate concerning BCB's actions, especially in universities. Third, schools that are sympathetic to the mainstream are defined as a function of what they research and teach. A considerable proportion of this teaching is derived from neoclassical theory, which constitutes, as shall be discussed, the contemporary orthodoxy. Non-mainstream schools may teach neoclassical economics, but they also include heterodox topics in their Economic curriculum.

\subsection{On the concepts of mainstream, orthodox, neoclassical and heterodox economics}

There is a relatively important discussion in the field of economic methodology and the history of economic thought concerning the impact of the terms "mainstream", "orthodoxy" and "heterodoxy". Among the various contributions to this literature Colander, Holt e Rosser Jr. (2004), Dequech (2007) and Dequech (2014) - the latter dealing particularly with Brazil show a relevant distinction regarding this paper's focus.

For Colander, Holt e Rosser Jr. (2004) mainstream must be defined as a set of ideas that the "elite of the profession" deems acceptable. According to the authors, the "elite of the profession" is the group formed by the leading economists in the top graduate schools. Since graduate schools are, in the academic context, a sort of hub from which the dominant knowledge is irradiated and reproduced, this elite also dominates strategic institutions such as scientific journals and academic associations. Thus, although the mainstream is a set of ideas, it is first and foremost a set of ideas accepted as legitimate within a certain circle of scientists. Therefore, mainstream is more than an intellectual strand, it is a social force and in this sense the term must be employed (Colander; Holt; Rosser Jr., 2004, p.490). ${ }^{10}$

Dequech (2007) broadened this definition, rendering it more usable and less normative, since he attenuates the idea of a hierarchy stemming from the above definition: "mainstream economics is that which is taught in the most prestigious universities and colleges, gets published in the most prestigious journals,

10 Furthermore, the notion of "edge of economics" is important, meaning the set of works that at a certain point of time that point towards the future path of the science of economics, the cutting edge developments, and those conducting it are certainly the members of the abovementioned elite of the profession (Colander et al., 2004). 
receives funds from the most important research foundations, and wins the most prestigious awards" (Dequech, 2007, p. 281). In plain terms, we could say that the concept of mainstream posited by Dequech (2007) encompasses the theories, techniques and edge topics managed by the elite of the profession and, in addition, the content taught by top colleges at their fundamental levels. Moreover, Dequech (2007) also includes in his definition of mainstream the professors and researchers who are not in an elite institution or professional circle, but teach or perform research within the set of mainstream ideas. According to the author, the emphasis on mathematical formalization, or, what is more, the reliance upon it would be the common thread to all of the mainstream (Dquech, 2007). ${ }^{11}$ Colander, Holt and Rosser Jr. (2004) argue that the mainstream is open to new ideas, but not new methodologies. For the elite of the profession "if it isn't modeled, it isn't economics, no matter how insightful." Mathematical models entail empirical techniques that can be applied accordingly.

As Colander, Holt and Rosser Jr. (2004) admit, the changes in the edge of economic thought are commonly not abrupt, but rather gradual. Thus, the fundamental teaching of the professional mainstream remains focused on transmitting the most basic tenets of the mainstream while in the cutting edge economic mainstream some ideas might be in contradiction to these basic principles. After a long process of assimilation, the new ideas from the cutting edge of the profession may or may not definitely enter the cannon.

As for the concept of orthodox economics, it involves "[...] the most recently dominant 'school of thought'" (Colander et al., 2004, p. 490). In this manner, the definition of orthodoxy does not refer to institutions (university department, graduate programs, scientific periodicals, etc.), or its practitioners (public economists, professors and university researchers), but it is a purely intellectual definition. This is so because its core is a minimum set of ideas, principles and assumptions, not a group of institutions and professionals. The most recent dominant school of economic thought is neoclassical economics.

According to Dequech (2007), neoclassicism encompasses the combination of the following characteristics: (1) emphasis on rationality and the use of maximization as a criterion of this rationality; (2) the emphasis on 11 The author notes that there are exceptions, as, for example, the Nobel Prize-winning work of Douglass North, but they remain rare (Dequech, 2007, p. 290). 
equilibria; and (3) the avoidance of fundamental uncertainty. In turn, the definition of Colander, Holt and Rosser Jr. (2004, p. 490-491) is almost identical, although the latter confers to the concept a more historical content, stating that Value and Capital (1939) by John Hicks, and Foundations of Economic Analysis (1947) by Paul Samuelson, are the paradigms of this kind of Economics.

On the relation between the mainstream and orthodox economics, we could argue that neoclassicism is a part of the former, although the mainstream contains edge ideas that at times are at odds with the main tenets of neoclassical economics. ${ }^{12}$ Among the perspectives that belong to the mainstream but are not strictly neoclassical, we include neo-institutionalism, behavioral economics, some propositions of transaction costs economics, and studies of economics and complexity and the theory of evolutionary games, among other strands (Dequech, 2007, p. 286; Colander; Holt; Rosser Jr., 2004, p. 496).

With regard to heterodoxy, we can define it in two different ways. First, it can be defined in a negative way, in opposition to orthodoxy or the mainstream, or even both. Second, heterodox economics can be defined in a positive manner, determining the research programs in economics whose principles and methodology are clearly different from the mainstream. Both Dequech (2007) as well as Colander, Holt and Rosser Jr. (2004) define heterodoxy in opposition to the dominant paradigms (the mainstream). Lee (2011), Lawson (2006), and Dow (2004), in turn, identify common (positive) traits among the various approaches in heterodox economics. In our opinion, considering the goals of this study, even if clearly identifiable common characteristics are absent, the fact is that Marxism, post-Keynesianism, evolutionary economics, Austrianism, original institutionalism, and structuralism have their own independent research agendas. These research programs are conveyed in specialized journals, associations, research networks, graduate and undergraduate syllabi, and textbooks. These are the defining elements of an identifiable scientific program. Of course, although they might pursue their own positive agenda, the economists working within this perspective devote much of their scientific practice to the critique of the mainstream. Indeed, they are working from marginalized perspectives.

12 Dequech (2007) states that his definition of mainstream can be applied to the period that begins in the 1990s. However, the first half of the previous decade can be included in this definition. 
The domination of the mainstream is certainly the state of affairs in American economics and, also, in the majority of the European research centers. However, Dequech (2014) applied the concept of mainstream to the Brazilian case with different results. He conducted an empirical research that extended, generalized and detailed previous studies on the discipline in Brazil. His results show that the international mainstream, as characterized above, differs considerably compared to the Brazilian mainstream. Dequech (2014) presents a detailed empirical analysis of the Brazilian mainstream; yet, his conclusions were somehow anticipated by other studies such as Anuatti Neto (1997), Prado (2001), and Versiani (2007). Regarding Brazil, in addition to the existence of important universities and research centers that seek to imitate the international mainstream, there are others where the teaching and research in economics is, in varying degrees, different from what is taught in international contexts.

Dequech (2014) analyzes graduate education, the ranking of specialized journals according to the Qualis-Capes system in the field of Economics, the concession of the academic prize of the Brazilian Association of Graduate Programs in Economics, the content of journals published in Brazil, and the theoretical-methodological proclivities of the recipients of the first rate productivity scholarship from the National Council for Scientific and Technological Development (CNPq). He concludes that at all these levels the presence of alternative research programs (heterodox) is significant - especially when compared to the US context. Surely, in Brazil, there are important graduate programs and research centers in line with the international mainstream. However, the general scenario is characterized by a greater pluralism. In the case of the post-Keynesian perspective, for example, there is a strong presence of affiliated economists with this perspective in the Brazilian economics academia. This is important because Post-Keynesians commonly diverge from mainstream economists regarding the management of monetary and currency policy.

\subsection{Mainstream and non-mainstream educational backgrounds}

To study the educational background of $\mathrm{BCB}$ directors, we must consider the particular context of the Brazilian academia in economics. It is important to take this different context into account because the pool of 
educational backgrounds from which the Brazilian central bankers are selected is much more varied in comparison with its American or European counterparts. In the following, we separate the types of educational backgrounds into two categories.

On one hand, there are the educational institutions in which the intellectual training is in accordance with the economic mainstream. Considering a few globally prestigious institutions, we observe a basic core of courses that are quintessentially neoclassical. For the period during which the majority of central bankers went to graduate school to earn $\mathrm{PhDs}$ abroad - the 1980s and 1990s - there was undeniably great homogeneity in the basic core of the neoclassical education, as reported by Hansen (1991, p. 1062-1063). ${ }^{13}$ In addition to this core, within this first type, the disciplines and the research programs that follow the basic core of formation are based either on the same neoclassical paradigm or on what has been termed above as the mainstream. In Brazil, the schools that follow this pattern and trained analyzed directors were Pontifical Catholic University of Rio de Janeiro (PUC-RJ) and Getúlio Vargas Foundation in Rio de Janeiro (FGV-RJ).

On the other hand, there is a distinct type of education, especially in some important Brazilian educational institutes, which, generally, include this basic core of neoclassical disciplines but, in subsequent stages, offers a variety of choices of disciplines based on other theoretical perspectives - what can be called the heterodoxy. In some Brazilian universities, intellectual training, even the most basic, is predominantly heterodox - as in Instituto de Economia da Universidade Estadual de Campinas (Unicamp) and, to a lesser extent, Instituto de Economia da Universidade Federal do Rio de Janeiro (Lessa; Earp, 2007) ${ }^{14}$. Although Unicamp did not train any of the appointed directors analyzed, the majority of those who graduated in Economics finished their studies at UFRJ (see Table 6). As to the University of São Paulo, Dequech (2014) notes that the existence of two areas of concentration in its graduate program in Economics is a sign, at least in part, of the plurality

13 Ten of the 14 directors of $\mathrm{BCB}$ with $\mathrm{PhDs}$ concluded in Brazil did so between 1986 and 2000. The other dates are 1972 are 1972, 1976, 1978 and 1979.

14 Hansen ( 1991) points out that there are some graduate schools in the United States that adopt non mainstream approaches. Examples are The New School for Social Research and the University of Massachusetts at Amherst. We could also add the University of Missouri in Kansas City as examples. For a global list of the programs that heterodox economists list as offering substantial disciplines and opportunities outside the mainstream, see Jo (2013). 
of its teaching. At the same time Prado (2001), who was a distinguished professor in the department for years, made a point of affirming this very same pluralism, as did Garófalo and Rizzieri (2007).

Figure 2 classifies the institutions where $\mathrm{BCB}$ directors in the considered span of time carried out their studies in Economics (exclusively), breaking them down into mainstream and non-mainstream.

Figure 2 Synthesis of the classification of university institutions with Economics degrees followed by Central Bank directors, 1995-2014

\begin{tabular}{l|l}
\hline Mainstream training & Nonmainstream training $^{15}$ \\
\hline Fundação Getúlio Vargas - Rio de Janeiro & Centro de Ensino Unificado de Brasília \\
\hline Harvard University & Pontifícia Universidade Católica - Minas Gerais \\
\hline Massachusetts Institute of Technology & Universidade de Brasília \\
\hline Oxford University & Universidade de São Paulo \\
\hline Pontifícia Universidade Católica - Rio de Janeiro & Universidade Estadual do Rio de Janeiro \\
\hline Princeton University & Universidade Federal de Minas Gerais \\
\hline Stanford University & Universidade Federal do Rio de Janeiro \\
\hline University of California, Berkeley ${ }^{16}$ & Paris 1 Panthéon-Sorbonne \\
\hline University of Illinois Urbana-Champaign & The Hebrew University of Jerusalem ${ }^{17}$ \\
\hline & École de Hautes Etudes Commerciales ${ }^{18}$ \\
\hline
\end{tabular}

Source: Observatory of social and political elites of Brazil (UFPR).

The name mainstream indicates that the institution follows an approach according to the definitions postulated by Dequech (2007), that is, as belonging to the international mainstream. The indication as non mainstream, preferable to heterodox or "plural", is employed here because the classification of schools of this second type deserves a more detailed study, which would take us too far afield.

15 The classification of the École de Hautes Etudes Commerciales and The Hebrew University of Jerusalem follows the same logic as Paris I Panthéon-Sorbonne, that is, given the difficulties of categorization they were classified as non mainstream.

16 One of the directors who trained at the doctoral level in this school graduated from the program "Regional Planning and Economics".

17 The director with a degree from the Hebrew University of Jerusalem graduated from a program in "Economics and Political Science". This same agent holds a degree in economics from the UFRJ.

18 The economics course the $\mathrm{BCB}$ director who graduated from this school completed is called "Economics and Public Administration." He also completed an undergraduate degree in "Political Science and International Relations" in the same school. 


\subsection{The educational backgrounds of BCB directors}

Table 4 presents a synthesis of educational degrees. We took into account all 39 directors of Central Bank and categorized their highest degree of education. We only considered stricto sensu degrees in Brazil. In case the director held a degree in Economics, we classified his training as mainstream or non-mainstream. Training in other disciplines was classified as nonmainstream. In this sense it is important to note that there is not a bias in this group in favor of a mainstream training.

Table 4 Directors of the Brazilian Central Bank according to university background

\begin{tabular}{|c|c|c|c|}
\hline & & \multicolumn{2}{|c|}{ Directors of the Brazilian Central Bank } \\
\hline & & Frequency & Percentage \\
\hline \multirow[t]{2}{*}{ Mainstream economic training } & Yes & 19 & 48.7 \\
\hline & No & 20 & 51.3 \\
\hline \multicolumn{2}{|l|}{ Total } & 39 & 100 \\
\hline
\end{tabular}

Source: Observatory of social and political elites of Brazil (UFPR).

Considering the directors with $\mathrm{PhD}$ degrees exclusively in Economics, of the 39 agents analyzed, 19 completed doctorate degrees, 18 of which in the field of economics. Table 5 shows the universities, the number and percentage of directors who obtained their $\mathrm{PhDs}$ in each one. Next, we present and discuss the classification of institutions. We consider only the highest degree of education as indicative of theoretical-methodological preferences because the choice of the graduate program, made at an age of greater maturity and large professional experience, constitute a more conscious option from the professional and even ideological point of view. ${ }^{19}$

As for the US universities, the formative origin of two-thirds of the $\mathrm{PhD}$ holding directors, the categorization as mainstream or non-mainstream begins with an analysis of the ranking of their Economics departments. A rather

19 It would be unfeasible to analyze the doctorate dissertations and/or publication (articles, research notes, opinion editorials, etc.) of these nineteen directors in order to determine their respective filiations to the dominant or non dominant strands of the discipline. In addition to the sheer volume and dispersion of this material, it would be necessary to consider that, since the majority of them are not "academics" (13 of the 19 come from the "government" or the "market") their scientific curricula (for example, those published in the CNPq Lattes database) were not available. Less than half of these $\mathrm{PhD}$ have a Lattes CV (42\%). Farvaque, Hammadou, and Stanek also use the $\mathrm{PhD}$ diploma as an important parameter, if only to predict the decisions of central bankers (Farvaque et al., 2009). 
broad-ranging research was conducted by Coupé (2003), wherein the author seeks to overcome the limits of previous investigations, besides elaborating upon data that correspond to a time span interesting for out study (19992000). He replicates in his database the methodology of Hirsch et al. (1984 apud Coupé, 2003), to compare his results to the time frame of 1978-1982. ${ }^{20}$

Table 5 Distribution of Central Bank Directors with doctorate degrees by country of origin and universities

\begin{tabular}{lrr}
\hline United States & $\mathbf{N}$ & $\mathbf{\%}$ \\
\hline Berkeley ${ }^{21}$ & 6 & 31.6 \\
\hline Harvard & 2 & 10.5 \\
\hline University of Illinois, Urbana Champaign & 2 & 10.5 \\
\hline Princeton & 2 & 10.5 \\
\hline Massachusetts Institute of Technology & 1 & 5.3 \\
\hline Stanford & 1 & 5.3 \\
\hline Subtotal & 14 & 73.7 \\
\hline Brazil & $\mathbf{N}$ & $\%$ \\
\hline Fundação Getúlio Vargas - Rio de Janeiro & 1 & 5.3 \\
\hline Universidade de São Paulo & 1 & 5.3 \\
\hline Universidade Federal de Minas Gerais & 1 & 5.3 \\
\hline Subtotal & 3 & 15.9 \\
\hline Europe & $\mathbf{N}$ & $\mathbf{\%}$ \\
\hline Oxford & 1 & 5.3 \\
\hline Paris 1 Panthéon-Sorbonne & 1 & 5.3 \\
\hline Subtotal & 2 & 10.6 \\
\hline Total & 19 & 100.0 \\
\hline
\end{tabular}

Source: Observatory of social and political elites of Brazil (UFPR).

The conclusions of Coupé (2003) place Harvard, MIT, Stanford, Berkeley and Princeton within the hard inner core of the international mainstream, for both in the intertemporal comparison with Hirsch's et al.'s ranking (Hirsch et al., 1984), and as a function of the two main criteria employed by the author, these institutions remained the top 15 . The

20 Hansen (1991) is also an important reference in this discussion, but he only studied graduate programs in the US.

21 One of the doctorate degrees offered by the University of Berkeley is in Urban Planning and Economics. 
Economics Department at the University of Illinois, Urbana-Champaign (UIUC), although not as highly ranked, remains close enough, among the top 30, both in Coupé's data (2003) and in the study containing the intertemporal analysis.

In Hansen's report (1991), the graduate programs are divided according to strata of quality. Among the 92 programs classified, Harvard, MIT, Princeton and Stanford were placed among the first (out of five) stratum. Berkeley was placed in the second tier, and UIUC in the third.22 Lastly, even when observing current rankings, these results are rather stable. Among the Economics departments of the US institutions mentioned, only UIUC is not among the top ten departments in the EconPhD.net website ranking, although it is ranked $53^{\text {rd }}$ in a total ranking of 223 institutions. The website ranking takes into account data from publications released between 1993 and 2003 (the chosen ranking, given that the website divides the field into subdisciplines, was macroeconomics, since this is the area most akin to activities of the Central Bank). In the Ideas website ranking updated monthly-once again the UIUC does not figure among the top ten (it is ranked $97^{\text {th }}$ among 249).23 This reinforces the conclusion that these departments not only belong but in fact constitute the inner hard core of the international mainstream. The studies authored by Coupé (2003) peremptorily come to the conclusion of US dominance in the science of Economics. What then is there to be said of the European departments where directors obtained their doctorate degrees?

Oxford University is well ranked in Coupé's study (2003) given that it remains among the top 30 regardless of the criteria adopted. In the annual website ranking by Ideas, its department is placed in a remarkable 5 th position. Also important in arriving to the conclusion that this distinguished UK department belongs to the mainstream is Lee's study (2007). Lee demonstrates how the requirements concerning publication performance in journals with impact factors - following the example of US departments generated a relatively swift process of expunging from these departments economists radically non-aligned to the mainstream.

22 The distribution among strata is deliberately unequal. Whereas the first stratum contains only 6 programs, the second, 9 , and the third 15, the remaining strata concentrate all other 92 graduate programs.

23 The rankings by Hansen (1991), Coupé (2003) and Hirsch et al. (1984) are the main ones cited here because the years the directors pursued their doctorate degree coincide with the periods of elaboration of these rankings. 
With respect to the Department of Economics at the University of Paris IPanthéon-Sorbonne, the conclusions are harder to be drawn. The data presented by Coupé (2003) shows this department in the 107th position, behind, for example, the University of Massachusetts at Amherst, cited by Hansen (1991) as an example of a department outside the mainstream. We also did not find data concerning the disciplines offered at the time this director pursued his studies there (1984). As this department is not as highly ranked as others, and as other evidence of mainstream belonging was absent, we preferred to classify it as non mainstream. An analysis of the disciplines currently offered in this institution's graduate course would point otherwise, although one of them is related to the history of economic, something incongruous to mainstream departments.

Among the doctorate degrees obtained in graduate programs in Brazilian departments, the classification was the same as described above. It is noteworthy however to underscore that FGV graduate school in economics was created with the intention of following a US-style curriculum. Firstly, the purpose was training Brazilian economists for entering in American graduate programs; afterwards they started their own graduate program in economics, always with the purpose of keeping abreast with the US mainstream academic output (Kafka, 1979; Versiani, 2007).

Doctorate training is important because it is the period during which the economist will engage intensely with the most advanced knowledge that will (supposedly) serve as the basis for future decisions. Nevertheless, it is also important to evaluate synthetically the undergraduate training of these economists because not all of them attained Ph.D. degrees.

Table 6 conveys information relative to the undergraduate backgrounds of directors who studied Economics. What stood out was that more than half of diplomas were obtained in two institutions based in the city of Rio de Janeiro: UFRJ and PUC-RJ. And, contrary to doctorates, only two directors studied abroad.

To state that undergraduate studies follow an international mainstream approach is a harder task since the variety and range of disciplines is much broader. Pursuant to Brazilian legislation, the bachelor's degrees courses require a large variety of courses as mandatory. Nonetheless, it would not be unreasonable to consider PUC-RJ, even at undergraduate level, as aligned with the international mainstream. Similarly, the UFRJ would be among the schools we classified as non mainstream, alongside the University of São Paulo, for the same reasons discussed above. 
Table 6 Educational background of BCB directors - Undergraduate institutions in Economics

\begin{tabular}{lrrr}
\hline Universities - Most frequent institutions & $\mathbf{N}$ & $\mathbf{\%}$ \\
\hline Universidade Federal do Rio de Janeiro - UFRJ & 7 & 30.4 \\
\hline Pontifícia Universidade Católica do Rio de Janeiro - PUC-Rio & 5 & 21.7 \\
\hline Universidade de Brasília - UnB & 3 & 13.0 \\
\hline Universidade de São Paulo - USP & 2 & 8.7 \\
\hline Universities - Others & $\mathbf{N}$ & \% \\
\hline Public universities (Brasil) & 2 & 8.6 \\
\hline Private universities (Brasil) & 2 & 8.6 \\
\hline Universities abroad ${ }^{24}$ & 2 & 8.6 \\
\hline Total & 23 & 100.0 \\
\hline
\end{tabular}

Source: Observatory of social and political elites of Brazil (UFPR).

As for University of Brasília, essential information is scarce. However, it would not be an exaggeration to admit that the teaching of the Economics Department of this university is predominantly mainstream, but with the presence of research opportunities in heterodox fields of the discipline. ${ }^{25}$ Our conclusion in this sense is based on a brief investigation of the heterodox-leaning economists among the faculty of this institution. Some stand out, such as Joanílio Rodolpho Teixeira, a 1A classified CNPq fellow, specialist in post-Keynesian macroeconomics, and a member of the department since 1977. Also Maria de Lourdes Rollemberg Mollo, a $\mathrm{CNPq} 1 \mathrm{~B}$ research fellow, has heterodox works and has been teaching in Brasília since $1981 .^{26}$ The hiring of these professors in the end of the 1970s and beginning of the 1980s, as well as the continuity of the hiring of other professors still in the faculty are a sign that, although the mainstream is dominant in the department, it is not closed off to other strands. Thus it has been classified as non mainstream. For schools that graduated only one of the directors we adopted the non mainstream classification. These schools were: UFMG, PUC-MG, UniCEUB / Brasília and the École des Haute Etudes Commerciales.

24 One of the directors graduated in Economics and Political Sciences from the Hebrew University of Jerusalem and in Economics at the UFRJ.

25 The years these directors graduated from the University of Brasília were: 1976, 1982, and 1984.

26 This information was collected from the institution's website and Lattes CNPq database. 
But why is it strategic to adopt the highest level of formation as the fundamental defining trait of the intellectual background as mainstream or non mainstream? When analyzing the overlap between mainstream and non mainstream institutions, considering that the directors could have done their undergraduate studies in a non mainstream department and then migrated to master's or doctorate in a mainstream institution, the result is clear: among the $19 \mathrm{PhDs}$ in Economics, 11 transitioned from the formers to the latter. Only three have their entire backgrounds in non mainstream institutions and four in entirely mainstream institutions Thus, the most common situation is that economists start their training in good public institutions that tend to be plural, such as UFRJ, USP and University of Brasília, and then go on to more advanced studies in mainstream institutions connected to the international mainstream.

\section{Economic mainstream and power}

Is the distribution among the types of directories among central bank agents random or is it correlated with their respective educational backgrounds?

An organization as complex as the Central Bank of Brazil has different decision-making bureaucratic levels one can discern by looking at the institution's formal organogram. It also counts on nuclei of power with differentiated capacities to influence government policies.

When created in 1964 (Law n. 4,595), it was established that BCB's structure would be composed by four heads (being one president and three directors). In the course of its institutional history there has been a series of variations in the number of direction positions, always upward, merging jurisdiction, changing of acronyms and other rearrangements according both to internal and external needs. ${ }^{27}$ Currently the Brazilian Central Bank is organized around a presidency and eight directories, as shown in Figure 3.

27 Directories that were created and then extinguished, such as the Public Debt Directory, created in 1980 and merged with the Banking Directory (later called Monetary Policy Directory) in 1990. All these changes can be viewed systematically in the document "Síntese das mudanças ocorridas na composição da diretoria, do Banco Central do Brasil". See <http:// www.bcb.gov.br/pre/historia/sintese_mud_estrutura.pdf>. Access on: February 2, 2015. 
Figure 3 Organizational Chart of Brazilian Central Bank: directories and presidency

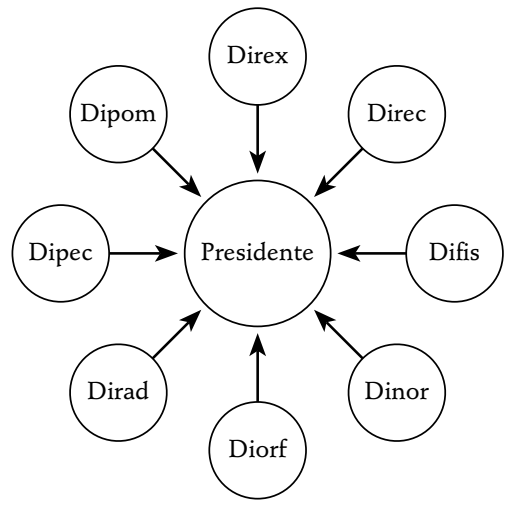

Source: Banco Central do Brasil.

The directories are: Administration (Dirad), Economic Policy (Dipec), monetary Policy (Dipom), International Affairs and Corporative Risk Management (Direx), and Institutional Relationship and Citizenship (Direc), Inspection (Difis), Oversight (Dinor) and Organization of Financial System and Control of Rural Credit Operations. Each one has different offices of information, advice and execution - the "departments" are hierarchically situated just below the directories. There are 28 departments in the Brazilian Central Bank. ${ }^{28}$ In this study we took into account the following divisions responsible for defining the economic policy, since they manage the main policy tools: Dipec, Dipom and Direx. ${ }^{29}$

The director of International Affairs and Management of Corporate Risk attribution is to "I. coordinate the evaluation of international conjuncture and its possible effects; II. Define and validate guidelines relative to the negotiations involving financial services and investments; [...]; IV articulate, when necessary, the positions to be defended by Central bank in forums and international agencies." The Director of Monetary Policy must: "I. accompany the evolution of aggregate monetary indicators in order to be able to adjust monetary and financial liquidity to the objectives of economic policy and obtain price stability; II. Administrate the application of

28 For an organizational chart with all its divisions, see <http://www.bcb.gov. br/?ORGANOGRAMA>. Access on: December 14, 2014.

29 For a complete list of the functions and responsibilities of each directory see the internal statute of BCB: <http://www.bcb.gov.br/Adm/RegimentoInterno/RegimentoInterno_2015>. 
monetary policy instruments and other instruments placed under his supervision; III. present in Copom meetings, suggestions concerning guidelines of monetary policy and the proposal of basic interest rate targets [...]" among other attributions. Lastly, the Director of Economic Policy has to "I. coordinate the studies and development of necessary models necessary to fulfill inflation targets; II. Coordinate: a) the monitoring, improvement and publication of macroeconomic data in the several areas (external, monetary, fiscal, interest rate and bank spread; b) the elaboration of an Inflation Report; [...] d) the elaboration of a trimestral Monetary Program; [...] g) lead activities with investors; [... [ III. evaluate the general economic situation and propose to the Collegiate Directory economic policy guidelines to assist deliberation and establish regulations in the subject". ${ }^{30}$

In the case of these directories, the bias in favor of economists with mainstream backgrounds is quite large: 15 of the 20 directors during both PT and PSDB periods who headed these divisions have this background as shown in Table 7.

Table 7 Distribution of BCB economic policy directories according to having a mainstream background or not

\begin{tabular}{|c|c|c|c|c|c|}
\hline & & & \multicolumn{2}{|c|}{ Economic policy formulation directories } & \multirow[t]{2}{*}{ Total } \\
\hline & & & No & Yes & \\
\hline \multirow{6}{*}{$\begin{array}{l}\text { Mainstream } \\
\text { economic } \\
\text { background }\end{array}$} & \multirow[t]{3}{*}{ No } & $\mathrm{N}$ & 15 & 5 & 20 \\
\hline & & $\%$ & $75.0 \%$ & $25.0 \%$ & $100.0 \%$ \\
\hline & & Adjusted residual & 3.4 & -3.4 & \\
\hline & \multirow[t]{3}{*}{ Yes } & $\mathrm{N}$ & 4 & 15 & 19 \\
\hline & & $\%$ & $21.1 \%$ & $78.9 \%$ & $100.0 \%$ \\
\hline & & Adjusted residual & -3.4 & 3.4 & \\
\hline \multirow{2}{*}{\multicolumn{2}{|c|}{ Total }} & $\mathrm{N}$ & 19 & 20 & 39 \\
\hline & & $\%$ & $48.7 \%$ & $51.3 \%$ & $100.0 \%$ \\
\hline
\end{tabular}

Source: Observatory of social and political elites of Brazil (UFPR).

Note: Value Cramer's V = 0.539; Approx. Sig. $=0001$

Nearly $80 \%$ of those who were appointed and served in Cardoso, Lula and Dilma governments in key BCB directory positions ("economic policy")

30 Decree $N^{\circ}$ 84.287, of February 27, 2015 (Regimento Interno do Banco Central do Brasil), pp. 20, 27-28, 26-27, respectively. See <http://www.bcb.gov.br/Adm/RegimentoInterno/ RegimentoInterno_2015.pdf $>$. April 8, 2015. 
were trained in institutions that we consider, according to the definition proposed in section 3 of this article, belonging to the economic mainstream. The adjusted standardized residuals above the critical range of 1.96 show that there is a significant positive association between education in a curriculum in Economics at mainstream schools and the possibility of heading a strategic division in Central Bank of Brazil (3.4 residuals) . The opposite is also true: the difference between the $21 \%$ (those without a mainstream education, but who eventually led Dipec, Dipom or Direx divisions) and $75 \%$ of cases (that do not have mainstream training and do not command boards responsible for defining the core of the government's economic policy) are statistically significant (3.4 residual). Therefore, this distribution is not random.

In order to illustrate more aptly the empirical magnitude of this finding we conducted a risk test evaluating the odds of someone in the mainstream being appointed to this position of power.

Table 8 Odds of agent occupying an economic policy directory in BCB after attending mainstream economics schools

\begin{tabular}{|c|c|c|c|}
\hline & \multirow[t]{2}{*}{ Value } & \multicolumn{2}{|c|}{$\begin{array}{r}\text { Confidence interval } \\
95 \%\end{array}$} \\
\hline & & Inferior & Superior \\
\hline Odds Ratio for mainstream background (no / yes) & 11.250 & 2.518 & 50.265 \\
\hline For the cohorts: economic policy formulation directories $=$ no & 3.563 & 1.439 & 8.822 \\
\hline For cohort: econmic policy directory $=$ yes & .317 & .143 & .700 \\
\hline $\mathrm{N}$ of Valid Cases & 39 & & \\
\hline
\end{tabular}

Source: Observatory of social and political elites of Brazil (UFPR).

Although the positions occupied by these agents are not pre-established, and in the absence of a definite political orientation in that sense, as we can see, an individual trained in accordance with the canon of international mainstream is eleven times more likely to occupy a position in the decision making boards that formulate economic policies compared to an individual without this training.

Finally, our study found that there is a significant association between attributes. As Table 3 shows, 12 directors came directly from the "market" to $\mathrm{BCB}$. Of these, nine had economic backgrounds in the mainstream of the discipline; and of those nine, seven were in posts responsible for draft- 
ing economic policy. On the other hand, the twenty who came from "government" (and, in general, the cadres of the Central Bank itself), 17 had training in non mainstream institutions. Of these 17, only two occupied monetary policy boards.

The above findings deal with the training and professional backgrounds of directors without drawing actual conclusions regarding their behavior during their time in $\mathrm{BCB}$. A natural extension of this work should assess whether the concentration of education in mainstream schools and non mainstream schools impacts on policy options, given the range of activities limited by board subtype of these policymakers. In addition, we believe that there is a relevant literature also within the field of Economic methodology, but with obvious extensions to macroeconomics and monetary economics, that seeks to synthesize whether there is a consensus within the mainstream in these specific fields of Economics. In Brazil this takes on particular importance because if the academic scenario here is different from the international mainstream, a central bank dominated by policymakers with a certain type of training produces dissonance between academic thinking and key positions of the occupants of this important institution of the Brazilian economy.

Data also showed that although the party that leads the coalition in the Executive Branch is different, although the climate of national economy is different, and the priorities of economic ministers are different, hardly anything changes in the profile of $\mathrm{BCB}$ directors over the interval studies.

In sum, the political autonomy of the bureaucratic agency and institutionalization of its routines and practices seem to be two self reinforcing processes, making it very hard for elected governments to abruptly change the profile of agents and preferences in terms o economic policy. The case of Brazil seems to illustrate that the sources for the construction of an ideological hegemony of the policies of orthodox control can bee also sought in the profile of those who command the Central Bank on an everyday basis.

\section{References}

ADOLPH, C. Bankers, Bureaucrates, and Central Bank Politics: the Myth of Neutrality. New York: Cambridge University Press, 2013.

AlbuQuerque, C. P. de. Os Bancos Centrais do Brasil e do Chile 1974-2005: um estudo comparado. Brasília - DF, Brasil: Universidade de Brasília, 2008. 
ANDRADE, J. P. de; MOLLO, M. de L. R.; SILVA, M. L. F. Os programas de estabilização na América Latina: traços ortodoxos e heterodoxos. Revista da Sociedade Brasileira de Economia Política, n.2, p.96-119, 1998.

ANUATTI NETO, F. Competição e complementaridade dos centros de pós-graduação em economia. In: 50 anos de Ciência Econômica no Brasil (1946-1996): pensamento, instituições, depoimentos. Petrópolis: Vozes, pp. 183-201, 1997.

BARBOSA, N.; SOUZA, J. A. P. de. A inflexão do governo Lula: política econômica, crescimento e distribuição de renda. In: SADER, E.; GARCIA, M. A. (Eds.). Brasil entre o Passado e o Futuro. São Paulo: Editora Fundação Perseu Abramo; Boitempo, 2010.

CODATO, A.; COSTA, L. D.; MASSIMO, L. Classificando ocupações prévias à entrada na política: uma discussão metodológica e um teste empírico. Opinião Pública, v.20, n.3, p.346-362, 2014.

COLANDER, D.; HOLT, R.; ROSSER, B. The Changing Face of Mainstream Economics. Review of Political Economy, v.16, n.4, p.485-499, 2004.

COUPÉ, T.; Revealed Performances: Worldwide Rankings of Economists and Economics Departments, 1990-2000. Journal of the European Economic Association, v.1, n.6, p.1309 -1345, 2003.

DAALDER, H.; BEERG, J. Members of the Dutch Lower: Pluralism and Democratization. In: Does Who Governs Matter? Chicago: Northern Illinois University Press, 1982.

DEQUECH, D. Aplicando o conceito de mainstream economics fora dos Estados Unidos e Europa: o caso do Brasil como um exemplo de pluralismo. In: 4a Conferência da European Society for the History of Economic Thought Latin America (ESHET Latin America). Belo Horizonte, MG, 2014.

DEQUECH, D. Neoclassical, Mainstream, Orthodox, and Heterodox Economics. Journal of Post Keynesian Economics, v.30, n.2, p.279-302, 2007.

DOW, S. C. Structured pluralism. Journal of Economic Methodology, v.11, n.3, p. 275-290, 2004.

FARVAQUE, É.; HAMMADOU, H.; STANEK, P. Select your Committee: The Impact of Central Bankers' Background on Inflation. Economie internationale, n.117, p.99-129, 2009.

FONSECA, P. C. D. Nem ortodoxia nem populismo: o Segundo Governo Vargas e a economia brasileira. Tempo, v.14, n.28, p.19-58, 2010.

GARÓFALO, G. de L.; RIZZIERI, J. A. B. O Departamento de Economia da FEA/USP e o pensamento econômico brasileiro. In: SZMRECSÁNYI, T. J.; COELHO, F. da S. (Eds.). Ensaios de história do pensamento econômico no Brasil contemporâneo. São Paulo: Atlas/Ordem dos Economistas de São Paulo, 2007.

GIAMBIAGI, F. et al. (Eds.) Economia brasileira contemporânea. Rio de Janeiro: Campus/Elsevier, 2011.

GÖHLMANN, S.; VAUBEL, R. The Educational and Occupational Background of Central Bankers and Its Effect On Inflation: An Empirical Analysis. European Economic Review, v.51, n.4, p.925-941, 2007.

HANSEN, L. The education and training of economics doctorates: Major findings of the executive secretary of the American Economic Association's commission on graduate education in economics. Journal of Economic Literature, v.29, n.3, p.1054-1084, 1991. 
HIRSCH, B. T. et al. Economics Departmental Rankings: Comment. American Economic Review, v.74, n.4, p.822-826, 1984.

JO, T. H. Informational Directory for Heterodox Economists. Graduate \& Undergraduate Programs, Journals, Publishers \& Book Series, Associations, Institutes, Blogs, and Other Websites, 5th ed., 2013.

KAFKA, A. Dr. Gudin e o Instituto Brasileiro de Economia da Fundação Getúlio Vargas. In: Eugênio Gudin visto por seus contemporâneos. Rio de Janeiro: Editora da Fundação Getúlio Vargas, 1979.

LAWSON, T. The nature of heterodox economics. Cambridge Journal of Economics, v.30, n.4, p.483-505, 2006.

LEBARON, F. European Central Bank Leaders in the Global Space of Central Bankers: A Geometric Data Analysis approach. French Politics, v.8, n.3, p.294-320, 2010.

LEE, F. S. A History of Heterodox Economics: Challenging the Mainstream in the twentieth century. New York: Routledge, 2011.

LEE, F. S. The Research Assessment Exercise, the State and the Dominance of Mainstream Economics in British Universities. Cambridge Journal of Economics, v.31, n.2, p.309-325, 2007.

LESSA, C.; EARP, F. S. Mais Além do II PND: O Instituto de Economia da UFRJ. In: SZMRECSÁNYI, T.; COELHO, F. S. (Eds.). Ensaios de história do pensamento econômico no Brasil contemporâneo. São Paulo: Atlas/Ordem dos Economistas de São Paulo, 2007.

LOUREIRO, M. R. Economistas e elites dirigentes no Brasil. Revista Brasileira de Ciências Sociais, v.7, n.20, p.47-65, 1992.

LOUREIRO, M. R. Os economistas no governo: gestão econômica e democracia. Rio de Janeiro: Ed. Fundação Getúlio Vargas, 1997.

MARCUSSEN, M. Ideas and Elites: The Social Construction of Economic and Monetary Union. Ålborg: Aalborg Universitetsforlag, 2000.

MORAIS, L.; SAAD-FILHO, A. Da economia política à política econômica: o novo-desenvolvimentismo e o governo Lula. Revista de Economia Política, v.4, n.124, p.507-527, 2011.

NOVELLI, J. M. N. A questão da continuidade da política macroeconômica entre o governo Cardoso e Lula (1995-2006). Revista de Sociologia e Política, v.18, n.36, p.227-240, 2010.

NOVELLI, J. M. N. Burocracia, dirigentes estatais e idéias econômicas: o caso do Banco Central do Brasil (1965-1998). Campinas - SP, Brasil: Universidade Estadual de Campinas, 1999.

OFFERLÉ, M. Professions et profession politique. In: OFFERLÉ, M. (Ed.). La profession politique: XIXe-XXe siècles. Paris: Belin, p. 7-35, 1999.

OLIVIERI, C. Política, burocracia e redes sociais: as nomeações para o alto escalão do Banco Central do Brasil. Revista de Sociologia e Política, v.29, p.147-168, 2007.

PERISSINOTTO, R. M. et al. (Eds.). Quem governa? Um estudo das elites políticas do Paraná, Curitiba: Editora UFPR, 2007.

PESTANA, M. H.; GAGEIRO, J. N. Análise de dados para ciências sociais: a complementaridade do SPSS 5th ed. Lisboa: Sílabo, 2008.

PRADO, E. F. S. A ortodoxia neoclássica. Estudos Avançados, v.15, n.41, p.9-20, 2001. 
RAPOSO, E. Banco Central do Brasil: o leviatã ibérico; uma interpretação do Brasil contemporâneo. São Paulo: Hucitec; PUC-Rio, 2011.

RODRIGUES, L. M. Partidos, ideologia e composição social: um estudo das bancadas partidárias na Câmara dos Deputados. São Paulo: Edusp, 2002.

SAWICKI, F. Classer les hommes politiques. Les usages des indicateurs de position sociale pour la compréhension de la professionnalisation politique. In: OFFERLÉ, M. (Ed.). La profession politique, XIXe-XXe siècle. Paris: Belin, pp. 135-170, 1999.

SOLA, L.; GARMAN, C.; MARQUES, M. Banco Central, autoridade política e governabilidade democrática. In: Banco Central: autoridade política e democratização: um equilíbrio delicado. Rio de Janeiro: Editora FGV, p. 113-159, 2002.

VERSIANI, F. Intercâmbio, verbas e pluralismo: a ANPEC na evolução do ensino e da pesquisa em economia no Brasil. In: SZMRECSÁNYI, T.; COELHO, F. S. (Eds.). Ensaios de história do pensamento econômico no Brasil contemporâneo. São Paulo: Atlas/Ordem dos Economistas de São Paulo, 2007.

\author{
About the authors \\ AdrianoCodato-adriano@ufpr.br \\ Departamento de Ciência Política, Universidade Federal do Paraná, Curitiba, PR. \\ Marco Cavalieri - cavaga@uol.com.br \\ Departamento de Economia, Universidade Federal do Paraná, Curitiba, PR. \\ Renato Perissinotto - monseff@gmail.com \\ Departamento de Ciência Política, Universidade Federal do Paraná, Curitiba, PR. \\ Eric Gil Dantas - ericgildantas@gmail.com \\ PPG Ciência Política, Universidade Federal do Paraná, Curitiba, PR.
}

\title{
About the article
}

Submission received on April 14, 2015. Approved for publication on July 23, 2015. 